\title{
PHYSICAL AND MECHANICAL PROPERTIES OF CONCRETE CONTAINING FIBERS FROM INDUSTRIAL CARPET WASTE
}

\author{
H. Mohammadhosseini' ${ }^{1}$, A.S.M. Abdul Awal ${ }^{2}$ \\ Construction Research Center, Faculty of Civil Engineering, Universiti Teknologi Malaysia (UTM) Skudai,81310, \\ Johor, Malaysia, ${ }^{1}$ hofa2018@yahoo.com, ${ }^{2}$ abdulawal@utm.my
}

\begin{abstract}
Fiber reinforcement can effectively improve the mechanical properties of concrete. Utilization of recycled fibers from postconsumer and industrial waste offer some benefits such as waste reduction and resource conservation and also low-cost materials and reduced need for landfilling. Carpets are one of the major components of waste materials around the world, which is 1-2\% of all solid wastes by volume. Industrial carpets are mainly made of polymeric materials such as Nylon and Polypropylene fibers. This study was carried out on different tests of the concrete containing fibers from Malaysian industrial carpet waste following the DOE mix design for the investigation of the physical and mechanical properties of concrete. Compressive, splitting tensile and flexural tests were performed with a fiber volume fraction range of 0.5-2\%. A decrease in compressive strength and workability was observed as a function of carpet fiber content. However, the addition of carpet fiber leads to enhance the splitting tensile strength, flexural strength and reducing the crack-size and a smoother mode of failure, unlike the brittle failure behavior of plain concrete.
\end{abstract}

Index Terms: Recycled fiber, Carpet waste, Fiber reinforced concrete, Physical and mechanical properties

\section{INTRODUCTION}

Concrete is a construction material used in a great quantity around the world. It has low tensile strength, low ductility and low energy absorption. Therefore, improving concrete properties and reducing the size and amount of defects in concrete would lead to better concrete performance. An effective way of improving these properties is by adding a small fraction (usually $0.5 \%-2 \%$ by volume) of short fibers to the concrete mix during the mixing process. Fibers in concrete, bridging the cracks in the matrix can provide resistance to crack propagation and crack open before being pulled out or stressed to rupture. Fibers are usually used in concrete to control plastic shrinkage cracking and drying shrinkage cracking. They also lower the permeability of concrete thus reduces bleeding of water. Some types of fibers produce greater impact abrasion and shatter resistance in concrete. Generally the tensile strength, ductility and the extent of post-cracking behavior of concrete depend on the strength characteristics and type and properties of fibers used in the concrete mix [1,2\&7]. Recently, many types of fibers are available in the concrete industry, and each type of fibers has their own properties, advantages and limitations. The selection of fibers is mainly based on the application of the concrete. The different types of fibers which are used in concrete are steel fibers, glass fibers, natural fibers, synthetic fibers (carbon and polypropylene), recycled fibers (carpet fibers, soft drink can fibers and steel fibers from the tire). Most of the fibrous waste is composed of natural and synthetic polymeric materials such as cotton, wool, silk, polyester, nylon, polypropylene, etc. These fibers are consumed and discarded in large quantities. Industrial waste refers to that generated in the manufacturing process of fiber products. The carpet industry is one of them which produced a large amount of waste materials and major part of these waste materials is fiber. These fibers are mainly 50\%-70\% nylon and $15 \%-25 \%$ polypropylene $[2,3,6 \& 9]$.

Polypropylene fibers from the industrial wastes are more applicable as the reinforcing fiber in concrete among other kinds of enhancement fibers due to the light weight, nonabsorbent of water and also good acid and alkali resistance, while it can reduce the weight of concrete because of its low density. Jinghai Zhou [4] found that the addition of recycled fiber decreases the compressive strength of concrete. When $0.06 \%$ of fibers added to the concrete mix, the compressive strength decreased by almost $11 \%$. A similar trend has been reported by Wang [1\&8], who observed a lower value of compressive strength of concrete containing carpet fibers compared to plain concrete. In the same research by Wang [2], he also found out that that addition of carpet fiber, significantly increased the energy absorption during flexural failure. The experimental result from Vilkner, et al. [5], shows that, inclusion of carpet fiber into concrete mix significantly reduced the workability and make it more difficult to consolidate and to achieve a high performance and low porosity.

\section{MATERIALS AND METHODS}

\subsection{Carpet fibers}

This fiber, as mentioned before is the product of cutting carpets in industries either from back or face yarn of carpet during the mixing process. The general outlook of a carpet shown in figure 1 . It consists typically of two yarns. The 
face yarn is most usually made of either polypropylene or nylon and most of industrial wastes are of these materials. The back yarn is made of the same materials as face yarn but they held together by adhesives with $\mathrm{CaCo}_{3}$ as filler.

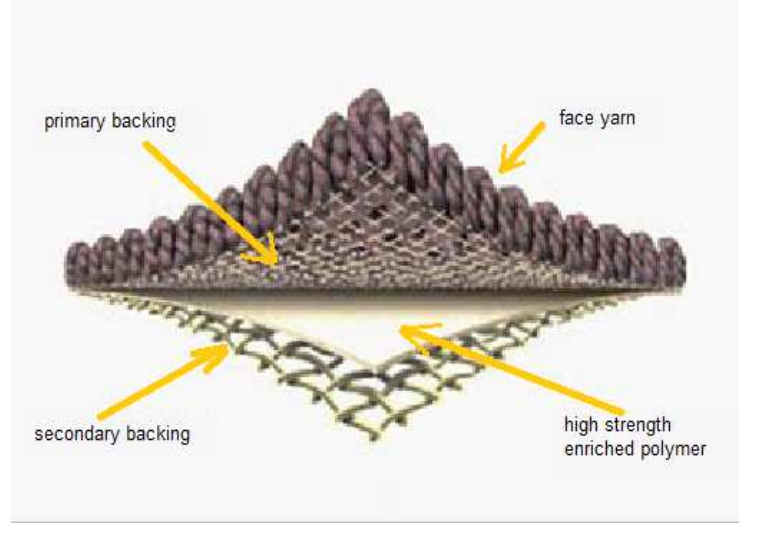

Fig -1: Typical carpet structure

In the present study, polypropylene carpet fiber was collected from ENTEX CARPET INDUSTIES SND. BHD in the Selangor, Malaysia. After collection, the fiber was tested for its properties such as density and tensile strength according the standard codes of practice. The fibers were $0.45 \mathrm{~mm}$ in diameter and the optimum length of $30 \mathrm{~mm}$ used in this study carried out by conducting a trail test. A flowchart for the preparation of carpet fiber is shown in Figure 2.

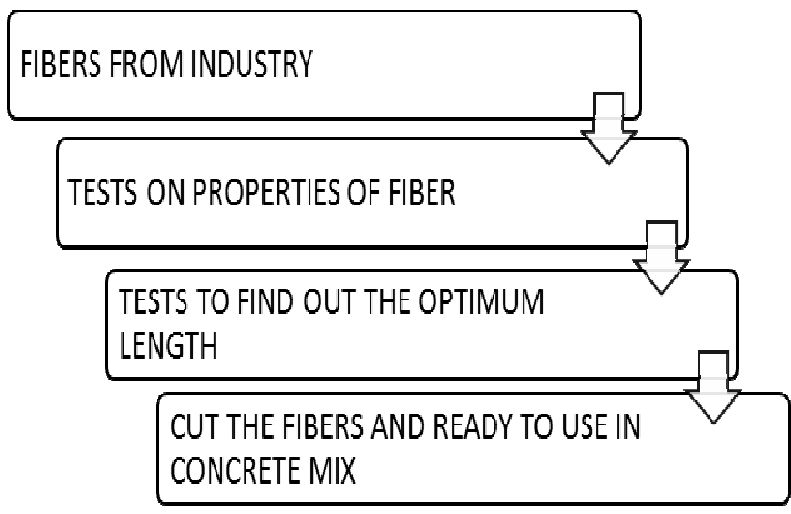

Fig -2: Flowchart for processing of carpet fibers

\subsection{Laboratory work and Test Procedure}

The manufacture of concrete specimens and all the tests on the fiber and concrete were carried out in the Structure and Materials Laboratory of the Faculty of Civil Engineering, Universiti Teknologi Malaysia (UTM). Ordinary Portland cement (OPC) was used throughout the experimental program. Table 1 reveals the properties of polypropylene carpet fibers used in this study. Natural sand and crushed granite of $10 \mathrm{~mm}$ size were used as fine and coarse aggregate respectively.

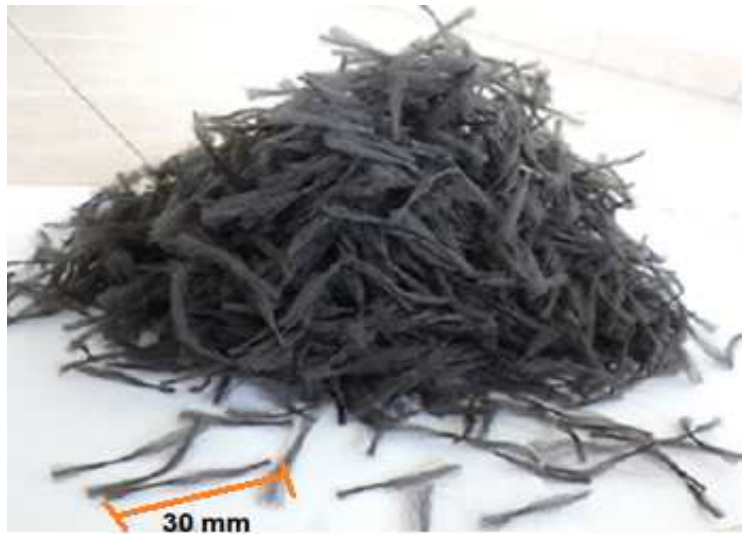

Fig -3: Typical polypropylene carpet fiber

Following DOE mix design method, plain concrete was made to have a target mean strength of $30 \mathrm{MPa}$ at 28 days with $30-60 \mathrm{~mm}$ slump. The detail of the mix proportion of plain concrete and concrete containing carpet fiber is shown in table 2. In this study, cylindrical specimens $(100 \mathrm{~mm} \mathrm{x}$ $200 \mathrm{~mm})$, cube specimens $(100 \mathrm{~mm}$ x $100 \mathrm{~mm}$ x $100 \mathrm{~mm})$ and prism specimens $(100 \mathrm{~mm} \times 100 \mathrm{~mm} \times 500 \mathrm{~mm})$ were prepared for splitting tensile strength, compressive strength and flexural strength respectively following the standards specified in BS 1881: Part 108 [12] and BS 1881: Part 110 [13].

Concrete containing carpet fibers were prepared in the same way as plain concrete and fiber volume fraction of $0.5 \%$, $1 \%, 1.5 \%$ and $2 \%$ without any additional admixtures. Carpet fiber was added to the concrete mixture uniformly throughout the mixing period. After casting, the specimens were de-molded at 24 hours and then put into the water tank for curing until testing. The average temperature recorded in the laboratory was $27 \pm 2{ }^{\circ} \mathrm{C}$ where the relative humidity, RH was $85 \pm 5 \%$.

Table -1: Test results on polypropylene carpet fiber

\begin{tabular}{|l|l|l|l|}
\hline $\begin{array}{l}\text { PP fiber } \\
\text { properties }\end{array}$ & Standard & Unit & Value \\
\hline $\begin{array}{l}\text { Tensile } \\
\text { strength }\end{array}$ & $\begin{array}{l}\text { ASTM } \\
\text { D638 }\end{array}$ & Psi & 4700 \\
\hline Density & $\begin{array}{l}\text { ASTM } \\
\text { D792 }\end{array}$ & $\mathrm{Kg} / \mathrm{m}^{3}$ & 945 \\
\hline $\begin{array}{l}\text { Reaction } \\
\text { with water }\end{array}$ & - & - & Hydrophobic \\
\hline $\begin{array}{l}\text { Melting } \\
\text { point }\end{array}$ & - & ${ }^{\circ} \mathrm{C}$ & 170 \\
\hline
\end{tabular}


Table -2: Mix proportion of PC and concrete containing carpet fiber (All units in $\mathrm{Kg} / \mathrm{m}^{3}$ )

\begin{tabular}{|l|l|l|l|l|l|}
\hline $\begin{array}{l}\text { Type of } \\
\text { concrete }\end{array}$ & $\begin{array}{l}\text { Free } \\
\text { water }\end{array}$ & Cement & $\begin{array}{l}\text { Fine } \\
\text { aggregate }\end{array}$ & $\begin{array}{l}\text { Coarse } \\
\text { aggregate }\end{array}$ & $\begin{array}{l}\text { Carpet } \\
\text { fiber }\end{array}$ \\
\hline PC & 215 & 430 & 840 & 910 & 0 \\
\hline $0.5 \%$ FRC & 215 & 430 & 840 & 910 & 4.73 \\
\hline $1.0 \%$ FRC & 215 & 430 & 840 & 910 & 9.45 \\
\hline $1.5 \%$ FRC & 215 & 430 & 840 & 910 & 14.18 \\
\hline $2.0 \%$ FRC & 215 & 430 & 840 & 910 & 18.90 \\
\hline
\end{tabular}

Notes: $\mathrm{PC}=$ plain concrete, $\mathrm{FRC}=$ carpet fiber reinforced concrete

Compressive, splitting tensile and flexural strength tests at the ages of 1, 7 and 28 days were conducted, and all the methods for measuring the strength of concrete specimens were in accordance with BS 1881: Part 116 [14] for compressive strength, ASTM C 496C/496M-11 [10] for splitting tensile strength and BS 1881: Part 118 [15] for flexural strength. Density and slump tests were also carried out for the fresh concrete in accordance with BS 1881: Part 107 [11] and BS EN 12350-2 respectively. The cube and cylinder specimens for compressive strength and splitting tensile strength were tested by concrete compression testing machine and prism specimens for flexural strength were tested by third-point loading method.

\section{TEST RESULTS AND DISCUSSION}

\subsection{Fresh Properties}

Workability is a property of concrete which investigate at fresh stage. Slump and density tests were carried out on the fresh concrete containing carpet fiber and plain concrete. It is important to note that slump value significantly reduced by adding carpet fiber into the concrete mix. For example, the slump value of plain concrete was obtained at $55 \mathrm{~mm}$. A slightly lower value of $40 \mathrm{~mm}$ was measured for $0.5 \%$ of the carpet fiber content. The addition of more fiber content reduced the slump value up to $10 \mathrm{~mm}$ for $2 \%$ carpet fiber. The wet density of concrete was also reduced by the addition of carpet fiber. This is to be expected, because of the low density of carpet fibers $\left(945 \mathrm{~kg} / \mathrm{m}^{3}\right)$ as compared to the OPC.

Table -3: Test results for plain and carpet fiber reinforced concrete

\begin{tabular}{|c|c|c|c|c|c|c|c|c|c|c|c|}
\hline \multirow[t]{2}{*}{$\begin{array}{l}\text { Type of } \\
\text { concrete }\end{array}$} & \multirow{2}{*}{$\begin{array}{l}\text { Slump } \\
\text { value } \\
(\mathrm{mm})\end{array}$} & \multirow[t]{2}{*}{$\begin{array}{l}\text { Density } \\
\left(\mathrm{kg} / \mathrm{m}^{3}\right)\end{array}$} & \multicolumn{3}{|c|}{$\begin{array}{l}\text { Compressive strength } \\
\text { (MPa) }\end{array}$} & \multicolumn{3}{|c|}{$\begin{array}{l}\text { Splitting tensile strength } \\
\text { (MPa) }\end{array}$} & \multicolumn{3}{|c|}{$\begin{array}{l}\text { Flexural strength } \\
\text { (MPa) }\end{array}$} \\
\hline & & & 1 day & 7 days & 28 days & 1 day & 7days & 28days & 1day & 7days & 28days \\
\hline PC & 55 & 2385 & 23.4 & 38.2 & 46.5 & 1.65 & 2.2 & 2.7 & 2.55 & 5.10 & 5.30 \\
\hline $\begin{array}{l}\text { FRC } \\
0.5 \%\end{array}$ & 40 & 2328 & 19.9 & 34.1 & 42.7 & 1.80 & 2.8 & 3.1 & 3.75 & 5.35 & 6.25 \\
\hline $\begin{array}{l}\text { FRC } \\
1.0 \%\end{array}$ & 20 & 2290 & 15.2 & 28.7 & 29.1 & 1.95 & 2.7 & 3.3 & 3.15 & 5.15 & 5.35 \\
\hline $\begin{array}{l}\text { FRC } \\
1.5 \%\end{array}$ & 15 & 2210 & 18 & 29.3 & 30.7 & 2.10 & 2.9 & 3.5 & 3.45 & 4.85 & 5.15 \\
\hline $\begin{array}{l}\text { FRC } \\
2.0 \%\end{array}$ & 10 & 2150 & 11.4 & 21.7 & 25.5 & 1.90 & 2.6 & 3.0 & 2.85 & 3.75 & 4.40 \\
\hline
\end{tabular}




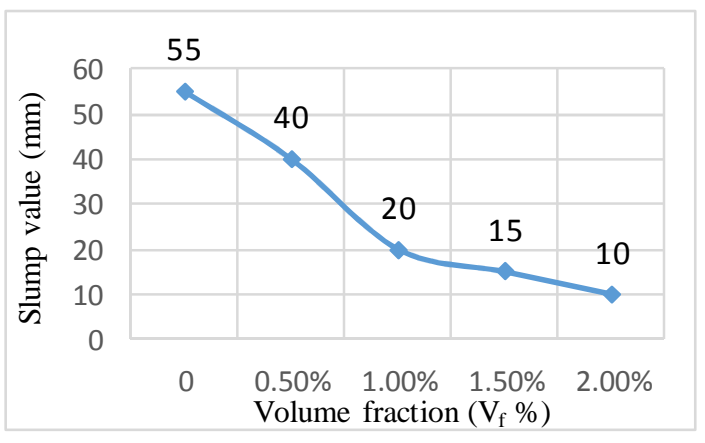

Fig -4: Slump values vs fiber volume fraction $\left(\mathrm{V}_{\mathrm{f}} \%\right)$

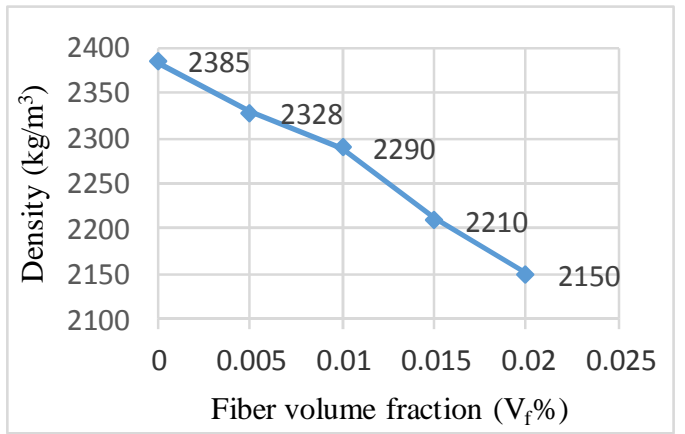

Fig -5: Concrete density vs volume fraction $\left(\mathrm{V}_{\mathrm{f}} \%\right)$

\subsection{Mechanical Properties}

Mechanical properties obtained from compressive, splitting tensile and flexural strength tests at the age of 1, 7 and 28 days are presented in the table- 3 . The result displayed in the table 3 , show that the compressive strength of concrete containing carpet fibers decreases with the addition and increasing the fiber volume fraction. The compressive strength decreases $8 \%$ for $0.5 \%$ carpet fiber content and about $45 \%$ for $2 \%$ carpet fiber content when compared to plain concrete. Figure 6 reveals the effect of fiber content on compressive strength of concrete. A similar trend has been reported by Vilkner, et al. [5] who observed, the lower value in a slump and compressive strength containing carpet fibers compared to the plain concrete.

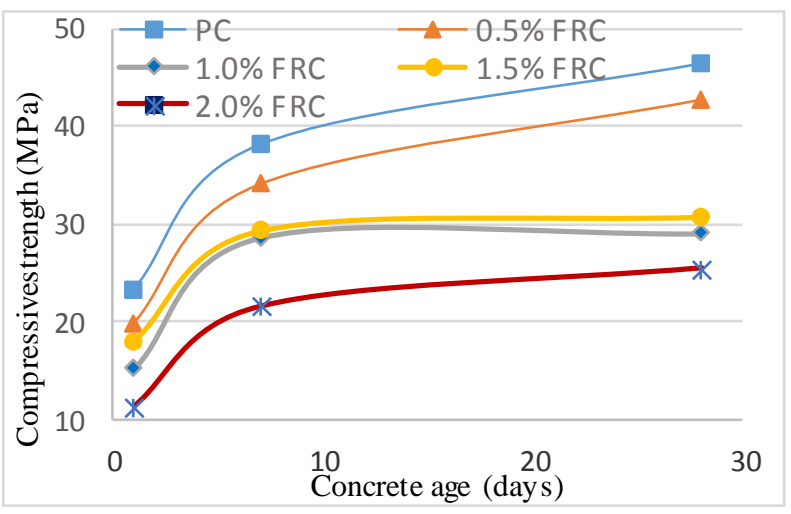

Fig -6: Compressive strength vs age of concrete

It can be seen from the data presented in table 3 that after adding the carpet fiber, concrete splitting tensile strength is obviously better than the plain concrete at all ages and fiber volume fractions. Compared the concrete containing carpet fiber with the plain concrete, when the volume of fiber was $0.5 \%$, the splitting tensile strength increased by about $14.7 \%$ and the splitting tensile strength was increased by about $30.4 \%$ for $1.5 \%$ carpet fiber. According to the data collected from this study, it is observed that the addition of carpet volume fraction improves the splitting tensile strength of concrete. The effects of the carpet fiber on the splitting tensile strength of concrete is clearly shown in the figure 7.

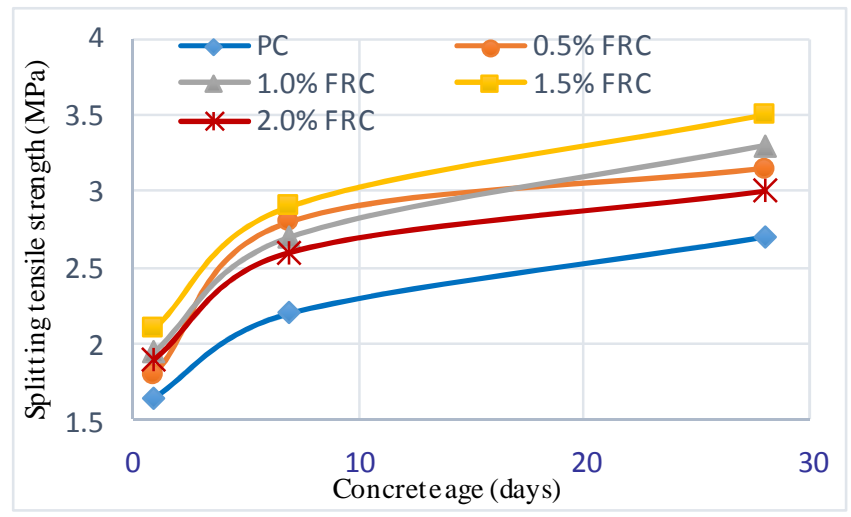

Fig -7: Splitting tensile strength vs concrete age

The results presented in table- 3 show that the flexural strength of concrete containing $0.5 \%$ carpet fibers at age 28 days increased by about $18.5 \%$ and $1.71 \%$ for $1 \%$ fiber. Further increase in the fiber content however, reduced the flexural strength. During the flexural strength test it has been observed that, by adding and increasing fiber volume fraction the mode of failure was smoother and the size of cracks was reduced. This is to be expected, due to bridging action provided by fibers which absorbed more energy and prevent the sudden failure of the specimen. A similar results have been reported by Marciano [6], who observed a lower value in flexural strength in concrete with textile fibers than in the plain concrete.

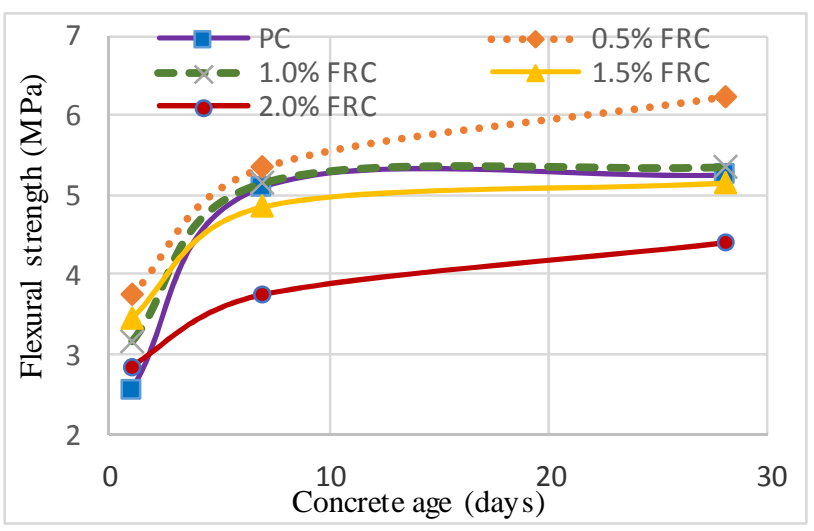

Fig -8: Flexural strength vs age of concrete 


\section{CONCLUSIONS}

Fiber reinforced concrete using carpet fiber has been studied, and found to be effective in improving the mechanical properties of concrete. The use of industrial waste carpet fiber offer the additional advantages of waste reduction and resource conservation. This paper reports experimental results on fresh and hardened properties such as workability and density and compressive, splitting tensile and flexural strength of concrete incorporating carpet fiber. Laboratory test data revealed that the workability and density were reduced with function of fiber volume fraction and compressive strength of concrete containing carpet fiber was somewhat lower than that of plain concrete. Concrete with carpet fiber like concrete made with other fibers, significantly increased in the splitting tensile and also flexural strength. The bridging action of carpet fibers caused smoother mode of failure and also reduced the size of cracks during bending load.

\section{ACKNOWLEDGEMENT}

The authors wish to express their gratitude towards the Structure and Materials Laboratory of the Faculty of Civil Engineering Universiti Teknologi Malaysia (UTM), for the technical supports in conducting the research work. Special thanks are due to ENTEX CARPET INDUSTIES SND. BHD, Selangor, Malaysia for providing waste carpet fibers.

\section{REFERENCES}

[1]. Y. Wang, Concrete reinforcement with recycled fibers from carpet industrial waste, Journal of materials in civil engineering, pp103-104, (1997).

[2]. Y. Wang, Fibre and textile waste utilization, Waste biomass, vol 1, pp135-143, (2010).

[3]. J. Herlihy, Recycling in the Carpet Industry, Carpet and Rug Industry, pp17-25, (1997).

[4]. Z. Jianghai, X. Hong, Research on mechanical properties of recycled fiber concrete, Applied Mechanics and Materials, Vol. 94, pp. 1184-1187, (2011).

[5]. G. Vilkner, C. Meyer and S. Shimanovich, Properties of glass concrete containing recycled carpet fibres, Columbia University, New York, USA, (2002).

[6]. M.L.R. Joao, Effect of Textile Waste on the Mechanical Properties of Polymer Concrete, Materials Research, Vol. 12, pp. 63-67, (2009).

[7]. Y. Wang, Utilization of recycled carpet waste fibers for reinforcement concrete and soil, wood head publishing Ltd., Cambridge, UK, (2006).

[8]. Y. Wang, H.C. Wu, C. Victor, Concrete reinforcement with recycled fibers, Journal of materials in civil engineering, pp314-319, (2000).

[9]. H. Schmidt, M. Cieslak, Concrete with carpet recycled: Suitability assessment by surface energy evaluation, Waste Management 28, pp1182-1187, (2008).

[10]. American Society for Testing and Materials, standard test method for splitting tensile strength of cylindrical concrete specimens, ASTM C496/ C496M-11, (2011).
[11]. British Standards Institution, Testing concrete. Method for determination of density of compacted fresh concrete, BS 1881-107, (1983).

[12]. British Standards Institution, Testing concrete. Method for making test cubes from fresh concrete, BS 1881-108, (1983).

[13]. British Standards Institution, Testing concrete. Method for making test cylinders from fresh concrete, BS 1881-110, (1983).

[14]. British Standards Institution, Testing concrete. Method for determination of compressive strength of concrete cubes, BS 1881-116, (1983).

[15]. British Standards Institution, Testing concrete. Method for determination of flexural strength, BS 1881-118, (1983).

\section{BIOGRAPHIES}

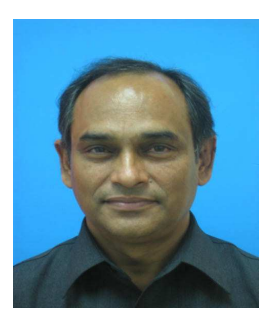

Dr. A.S.M. Abdul Awal is currently working as an international academic staff in the Department of Structure and Materials, Faculty of Civil Engineering of the Universiti Teknologi Malaysia (UTM). Prior to joining UTM, he was a Professor in the Department of Farm Structure, Bangladesh Agricultural University at Mymensingh. Professor Abdul Awal has over thirty years of teaching and research experience in the area of cement and concrete technology. $\mathrm{He}$ is the pioneer researcher in utilizing palm oil fuel ash (POFA) in producing high performance concrete, and in recent past has introduced the concept of high volume POFA in green concrete construction. Apart from teaching and research, he is also well known for his interest and commitment to collaborate $\mathrm{R} \& \mathrm{D}$ activities for the betterment of local and global community.

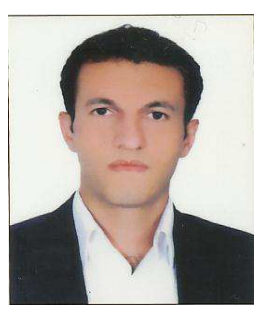

Hossein Mohammadhosseini has received his Bachelor degree in Civil Engineering from Pune University India in 2011. Currently he is doing Master of Structural Engineering (ME) at the Universiti Technologi Malaysia (UTM). Before start master coarse he worked as site engineer in Iran for one year. His research interests includes fiber reinforced concrete and high performance concrete. 